\title{
Isotopic characterization of coal mine methane in the Upper Silesian Coal Basin, Poland
}

Alina Fiehn" ${ }^{1}$, Julian Kostinek ${ }^{1}$, Maximilian Eckl ${ }^{1}$, Michal Galkowski' ${ }^{2,3}$, Christoph Gerbig ${ }^{2}$, Thomas Röckmannn ${ }^{4}$, Malika Menoud ${ }^{4}$, Hossein Maazallahi ${ }^{4}$, Martina Schmidt ${ }^{5}$, Piotr Korben ${ }^{5}$, Jaroslaw Necki ${ }^{3}$, Mila Stanisavljevic ${ }^{3,6}$, Justyna Swolkien ${ }^{6}$, Anna-Leah Nickl ${ }^{1}$, Franziska Winterstein ${ }^{1}$, Mariano Mertens ${ }^{1}$, Patrick Jöckel ${ }^{1}$, Andreas Fix ${ }^{1}$, Anke Roiger ${ }^{1}$

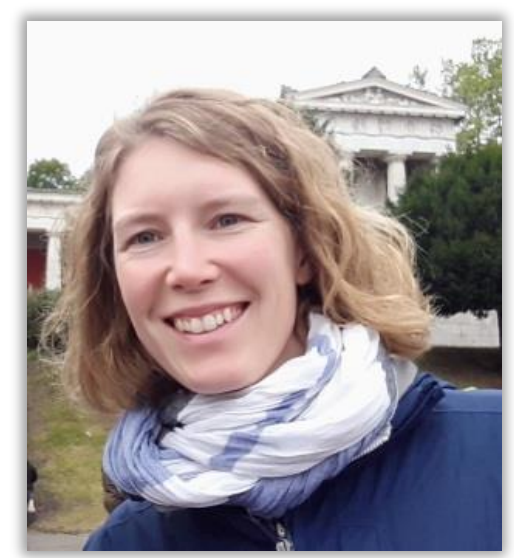

${ }^{1}$ Deutsches Zentrum für Luft- und Raumfahrt (DLR), Institut für Physik der Atmosphäre, Oberpfaffenhofen, Germany

2 Max-Planck-Institut für Biogeochemie (MPI-BGC), Jena, Germany

${ }^{3}$ Faculty of Physics and Applied Computer Science, AGH University of Science and Technology, Kraków, Poland

${ }^{4}$ Institute for Marine and Atmospheric research Utrecht, Utrecht University, Utrecht, The Netherlands

${ }^{5}$ Institute of Environmental Physics, University of Heidelberg, Heidelberg, Germany

${ }^{6}$ Faculty of Mining and Geoengineering, AGH University of Science and Technology, Kraków, Poland

EGU21-6056

alina.fiehn@dlr.de

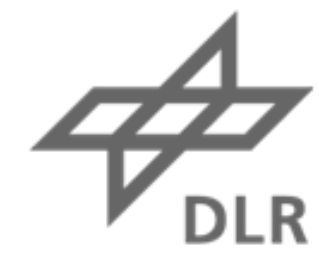




\section{Content}

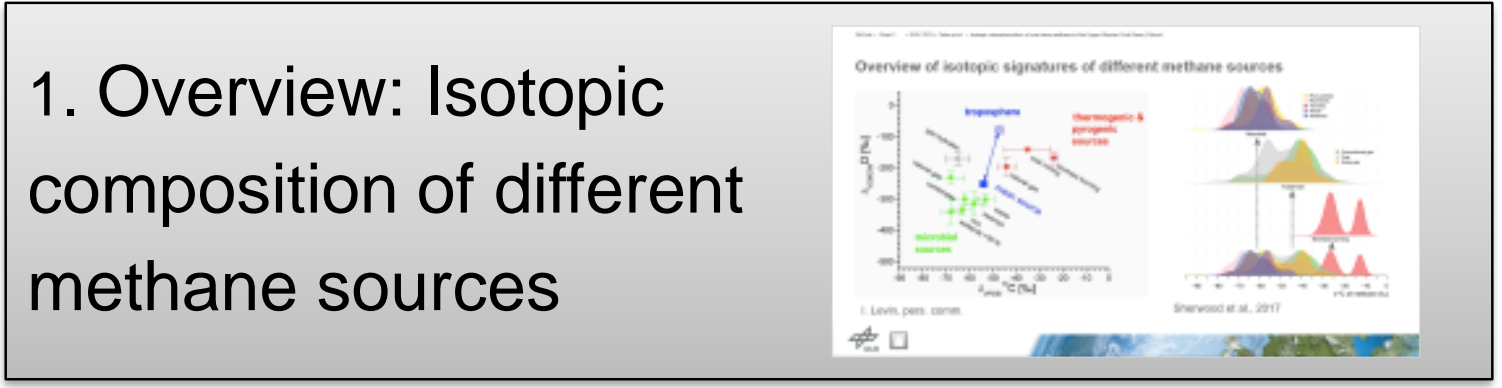

4. Single-shaft isotopic signatures

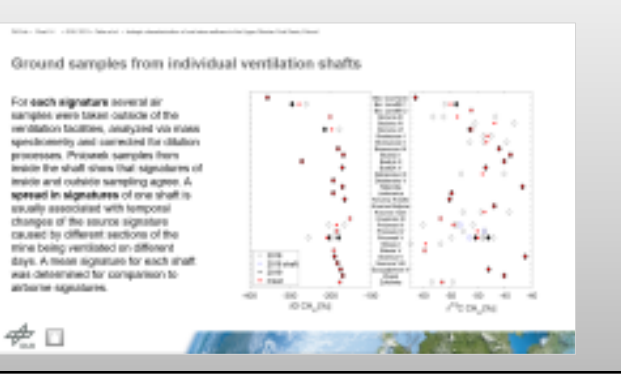

2. The CoMet mission overview

3. USCB isotopic signatures of methane

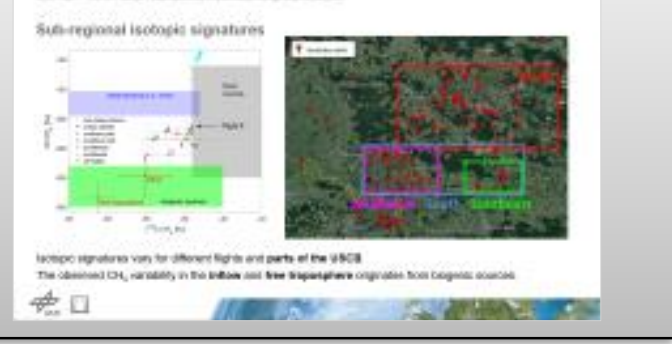

6. Conclusions
5. Simulation of methane isotopologues with $\operatorname{MECO}(n)$

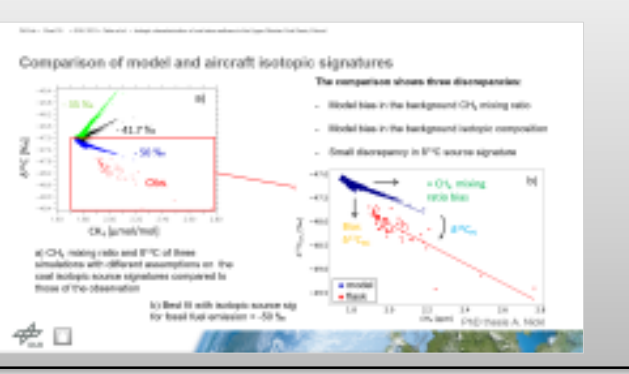

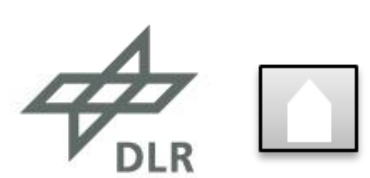




\section{Overview of isotopic signatures of different methane sources}

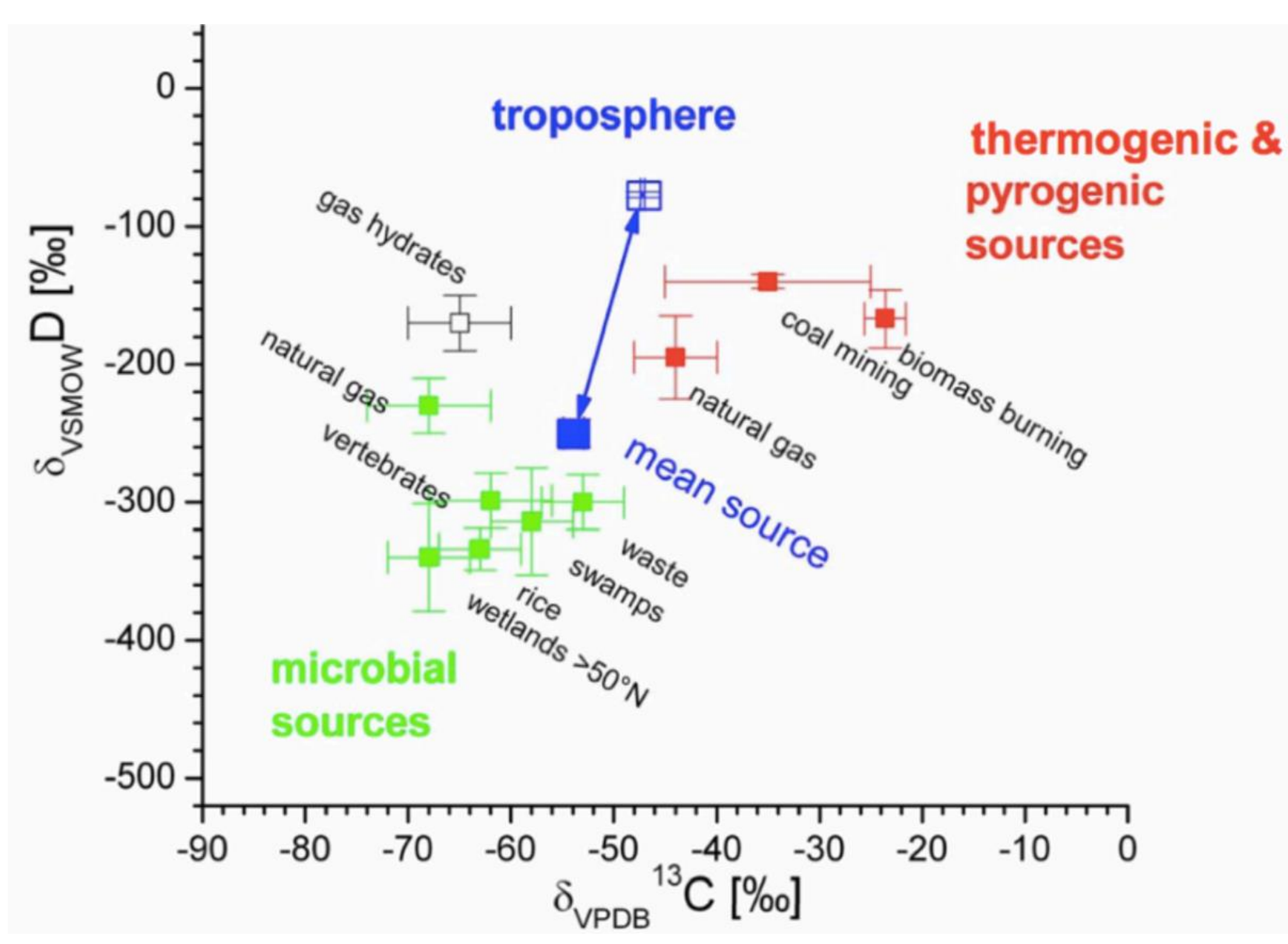

I. Levin, pers. comm.

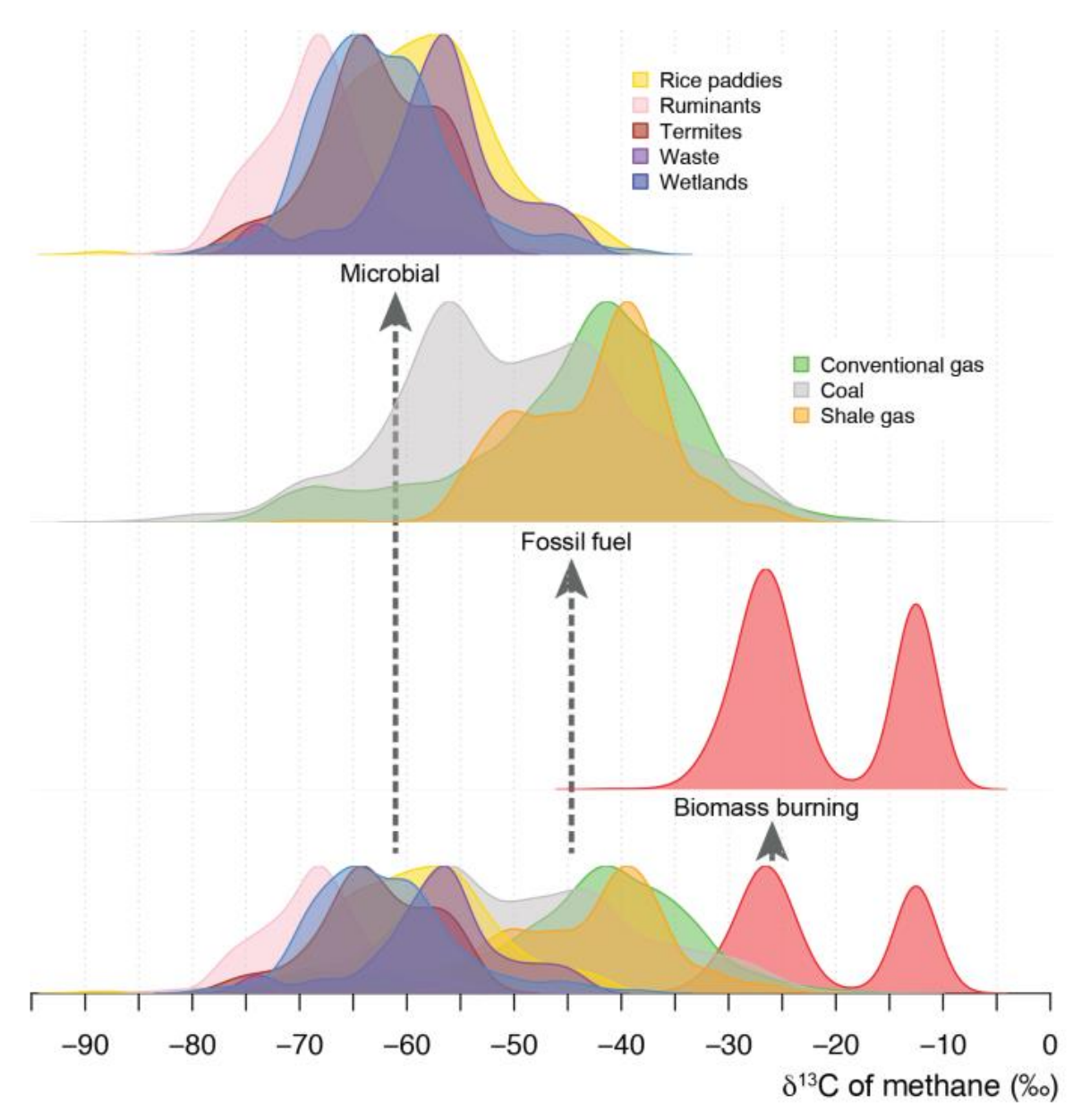

Sherwood et al., 2017

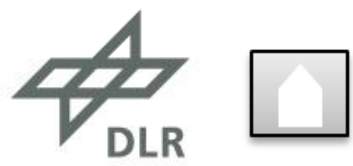




\section{Upper Silesian Coal Basin signatures from literature}

\begin{tabular}{|c|c|c|c|}
\hline Reference & d13C CH4 $[\% 0]$ & dD CH4 [\%o] & Comment \\
\hline Kotarba et al., 2001 & -79.9 to -44.5 & -202 to -153 & Samples from boreholes inside the coal seam \\
\hline Kotarba et al., 2004 & -72.8 to -47.8 & -196 to -153 & Samples from boreholes inside the coal seam \\
\hline Necki et al., 2017 & -49.0 & n.a. & Samples from inside ventilation shafts \\
\hline Galkowski et al., 2021 & $-50.9 \pm 1.1$ & $-224.7 \pm 6.6$ & $\begin{array}{l}\text { CoMet } 1.0 \text { HALO aircraft observations, entire } \\
\text { USCB ( } 2 \text { flights) }\end{array}$ \\
\hline Stanisavljevic et al., in prep. & $-50.2 \pm 9.2$ & $-180.1 \pm 38.2$ & $\begin{array}{l}\text { Weighted average of single mine } \\
\text { isotopic signatures (weighting by measured } \\
\text { fluxes or fluxes reported by E-PRTR) }\end{array}$ \\
\hline
\end{tabular}




\section{The CoMet mission overview}

Special Issue: CoMet: a mission to improve our understanding and to better quantify the carbon dioxide and methane cycles (AMT/ACP/GMD inter-journal SI), 2019 Eds. ACP co-editors | Coordinators: Martin Dameris and Christoph Gerbig
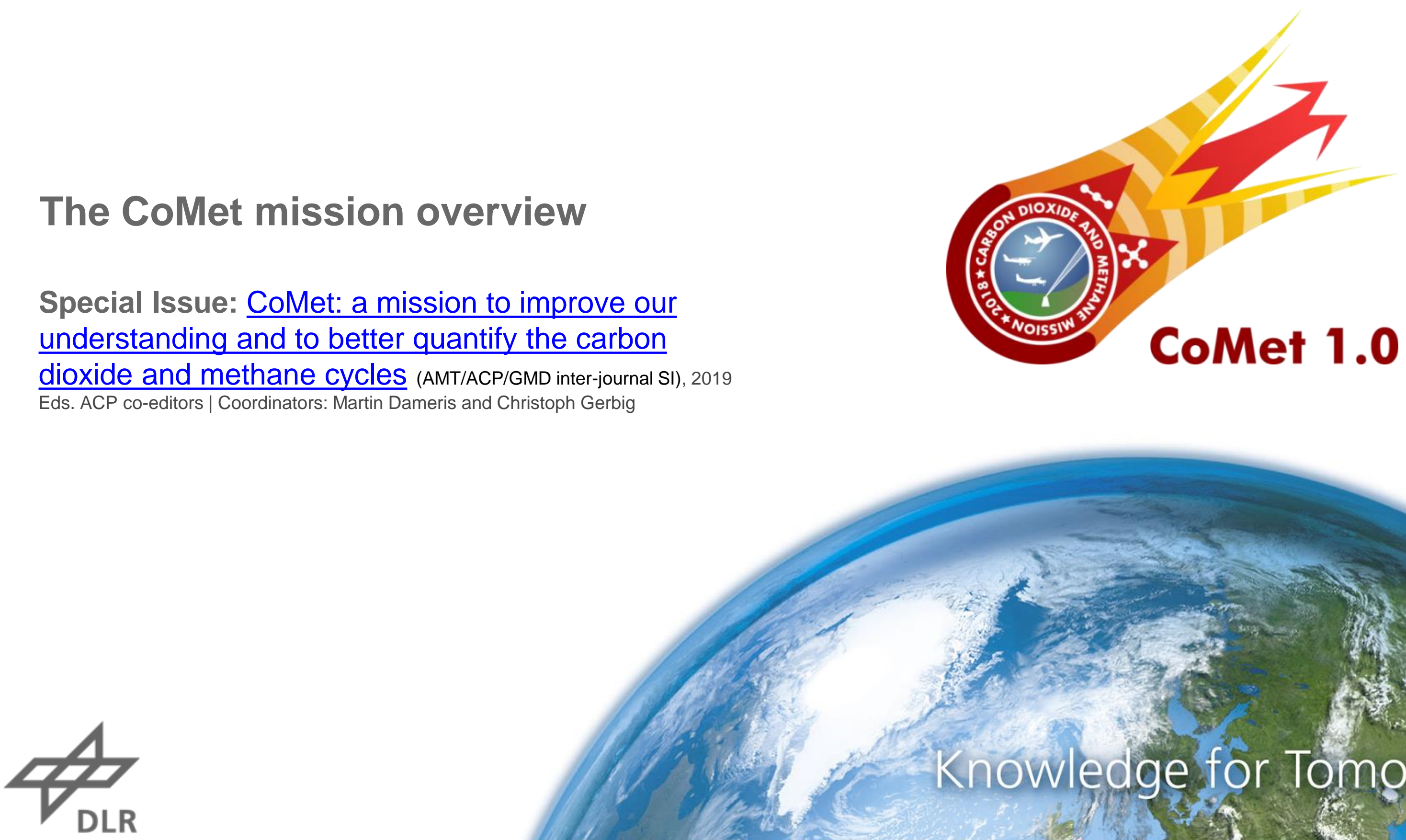


\section{Introduction to the $\underline{\mathrm{CO}}_{2}$ and Methane Mission (CoMet)}

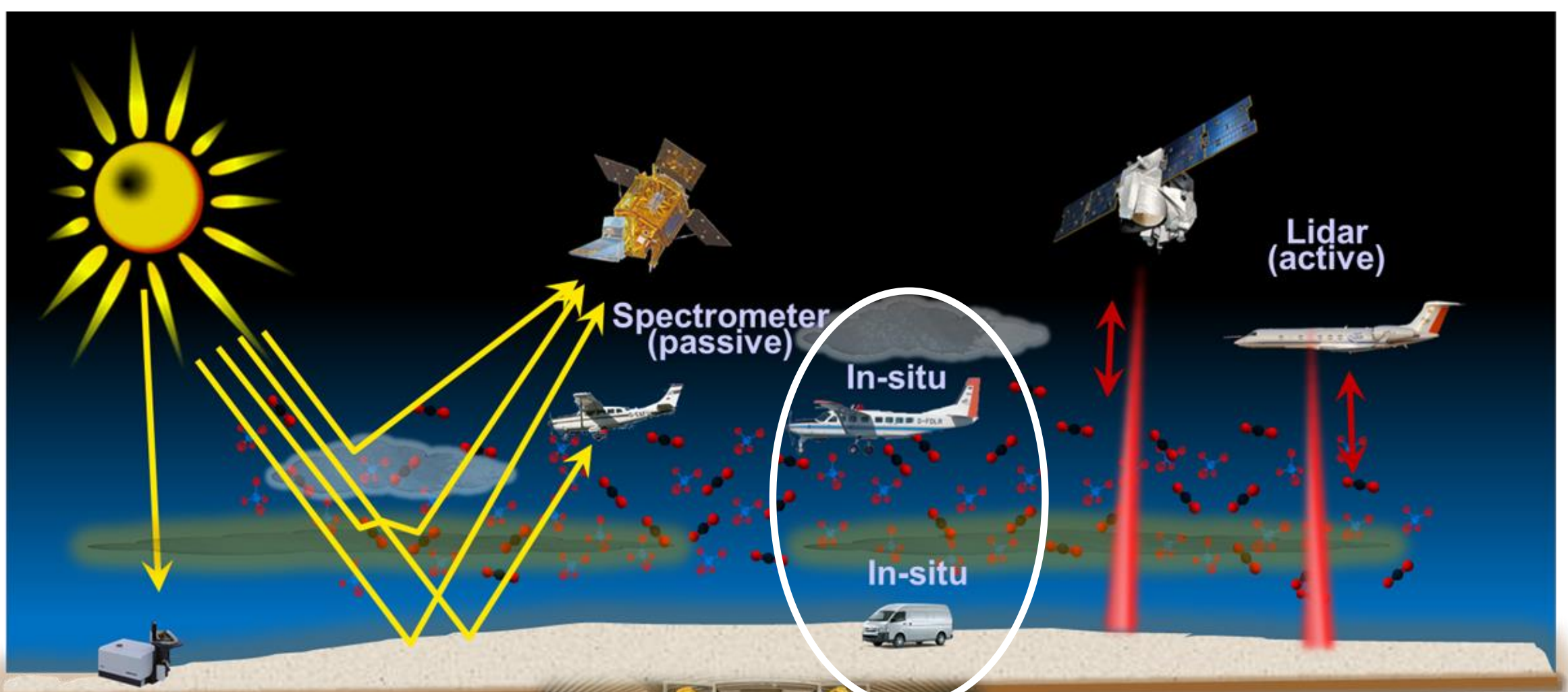

Realization of active and passive remote sensing as well as in situ observations of greenhouse gases from satellite, aircraft and ground platforms. 


\section{FDLR Cessna Instrumentation}

CRDS Picarro G1301-m: $\mathrm{CO}_{2}, \mathrm{CH}_{4}, \mathrm{H}_{2} \mathrm{O}$ (Klausner et al., 2020)

Aerodyne QCLS: CO, $\mathrm{C}_{2} \mathrm{H}_{6}, \mathrm{CO}_{2}, \mathrm{CH}_{4}, \mathrm{~N}_{2} \mathrm{O}, \mathrm{H}_{2} \mathrm{O}$ (Kostinek et al., 2019)

Flask sampler: Isotopes, Jena Air Sampler (JAS)

MetPod: T, p, $\mathrm{H}_{2} \mathrm{O}$, 3D-wind (Mallaun et al., 2015)

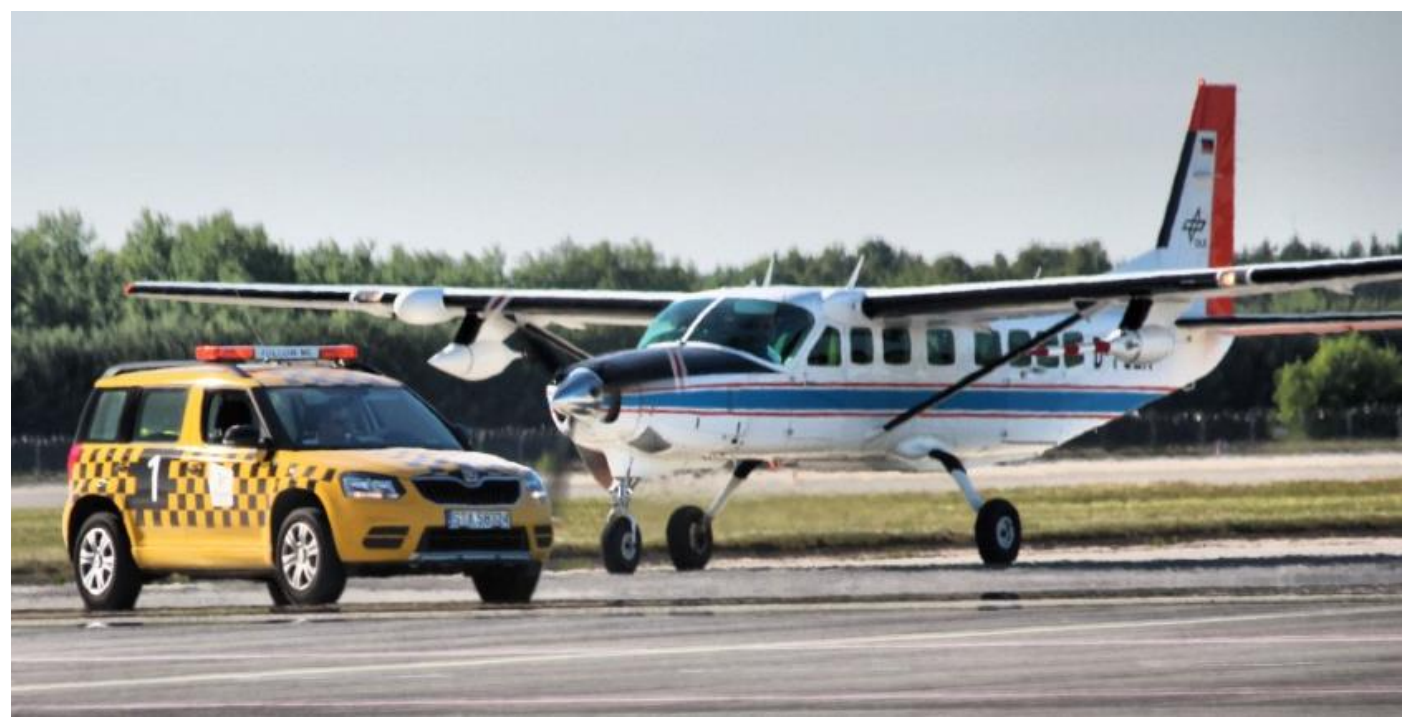

Katowice, Silesia, Poland

28.05. -

14.06.2018
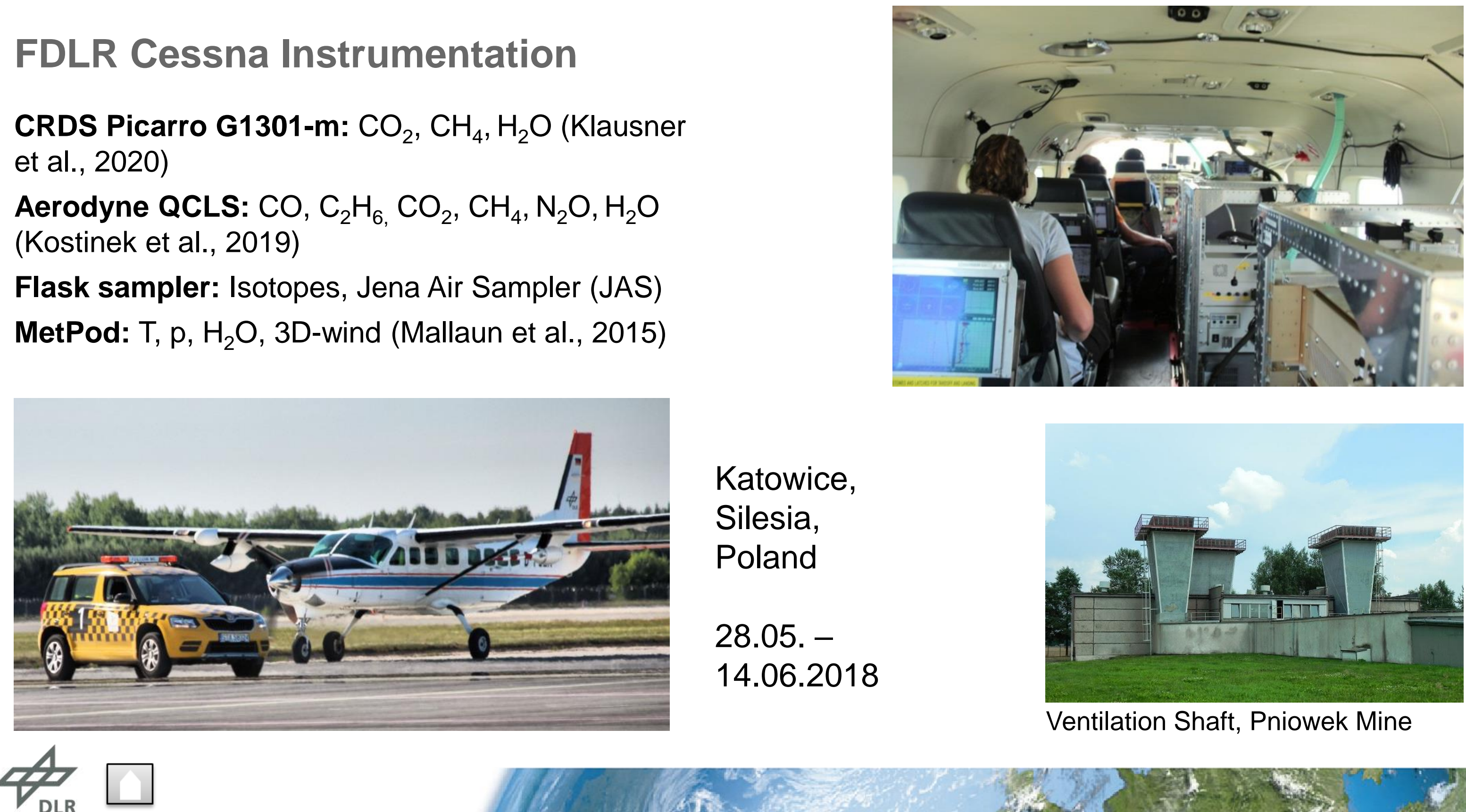

Ventilation Shaft, Pniowek Mine 
USCB emission estimate from mass balance and comparison with inventories

The $\mathrm{CH}_{4}, \mathrm{CO}_{2}$, and $\mathrm{CO}$ emissions of the entire USCB have been assessed from flights 4 and 5 with an airborne mass balance technique.

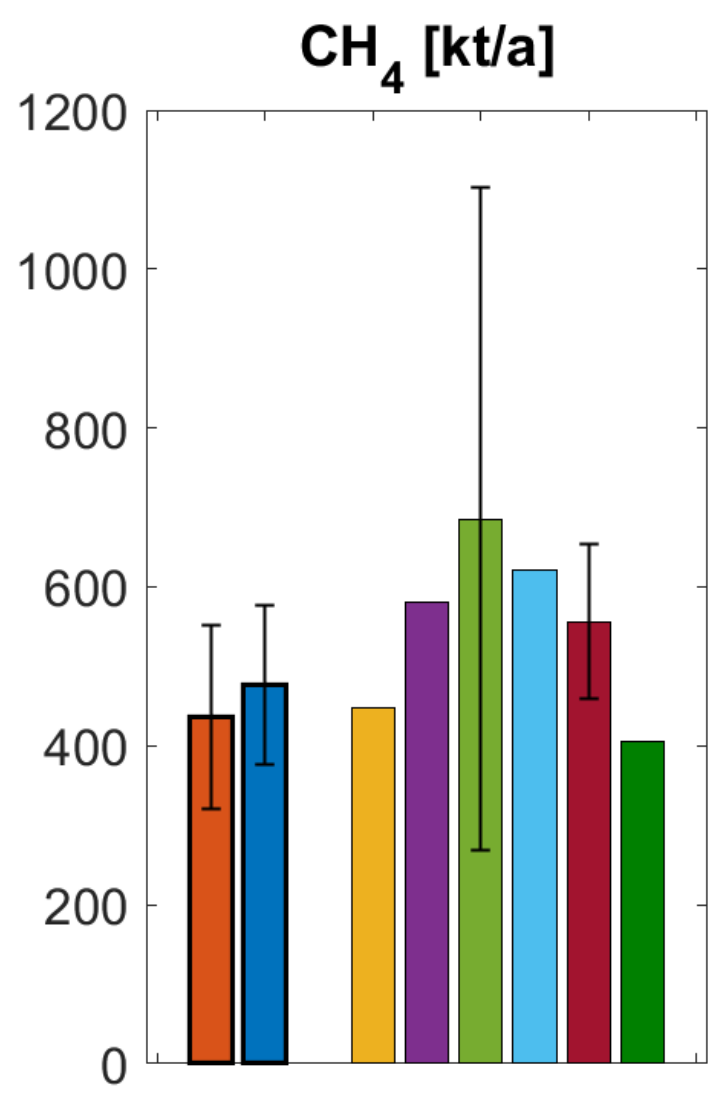

$\mathrm{CH}_{4}$ : Airborne estimate in the lower range of the six presented emission inventories.

$\mathrm{CO}_{2}$ : Second flight constrains the emissions to the lower end of inventory values.

CO: In range of inventories.

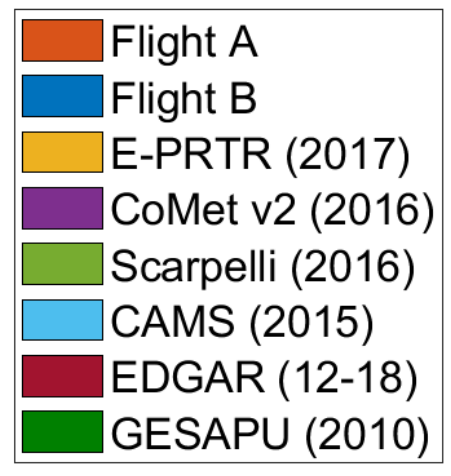

published by Fiehn et al., 2020, ACP 


\section{Airborne flask samples, analysis with mass spectrometry at MPI-BGC Jena}

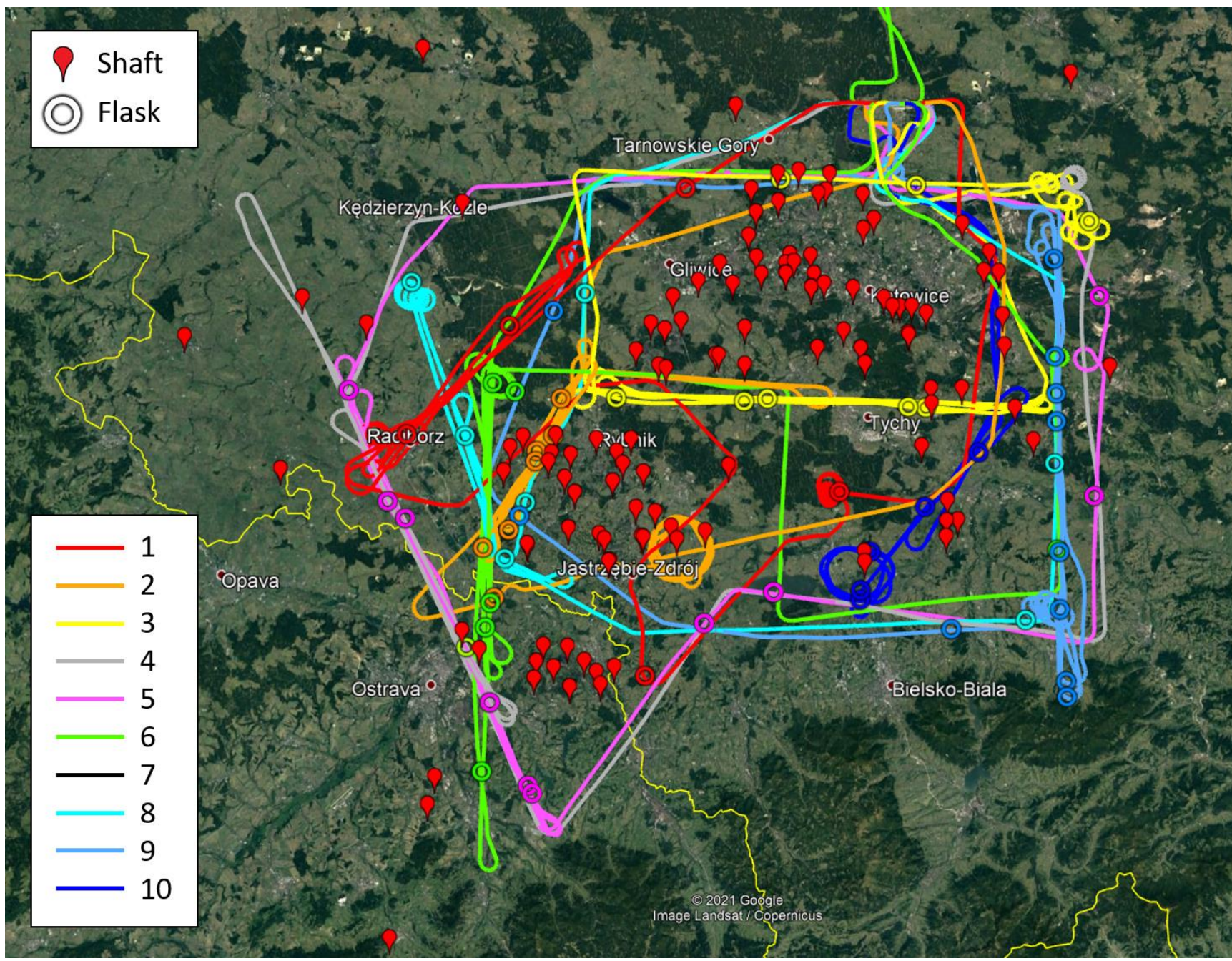

A Jena Air Sampler (JAS) with 12 glass flasks was installed on the Caravan aircraft. The samples were analyzed for trace gas concentrations and isotopic ratios of methane. JAS and the analysis are described by Galkowski et al. (2021).

Samples are distinguished in three categories according to their location with respect to the sources:

\begin{tabular}{|l|l|l|}
\hline & Sampling location & $\mathbf{\#}$ \\
\hline ALL & TOTAL & $\mathbf{5 5}$ \\
\hline FT & Free Troposphere & 15 \\
\hline IN & Inflow (upwind, PBL) & 8 \\
\hline PL & Plumes (downwind, PBL) & 32 \\
\hline
\end{tabular}

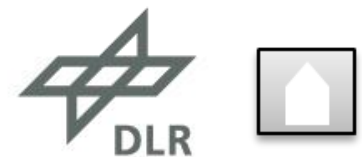




\section{Determination of source signatures from airborne samples}

$c_{s}+c_{b g}=c_{\text {tot }} \quad(s:$ source; $b g$ : background $)$

$c_{s} * \delta_{s}+c_{b g} * \delta_{b g}=c_{t o t} * \delta_{t o t} \rightarrow \delta_{t o t}=c_{b g}\left(\delta_{b g}-\delta_{s}\right)\left(1 / c_{t o t}\right)+\delta_{s}$

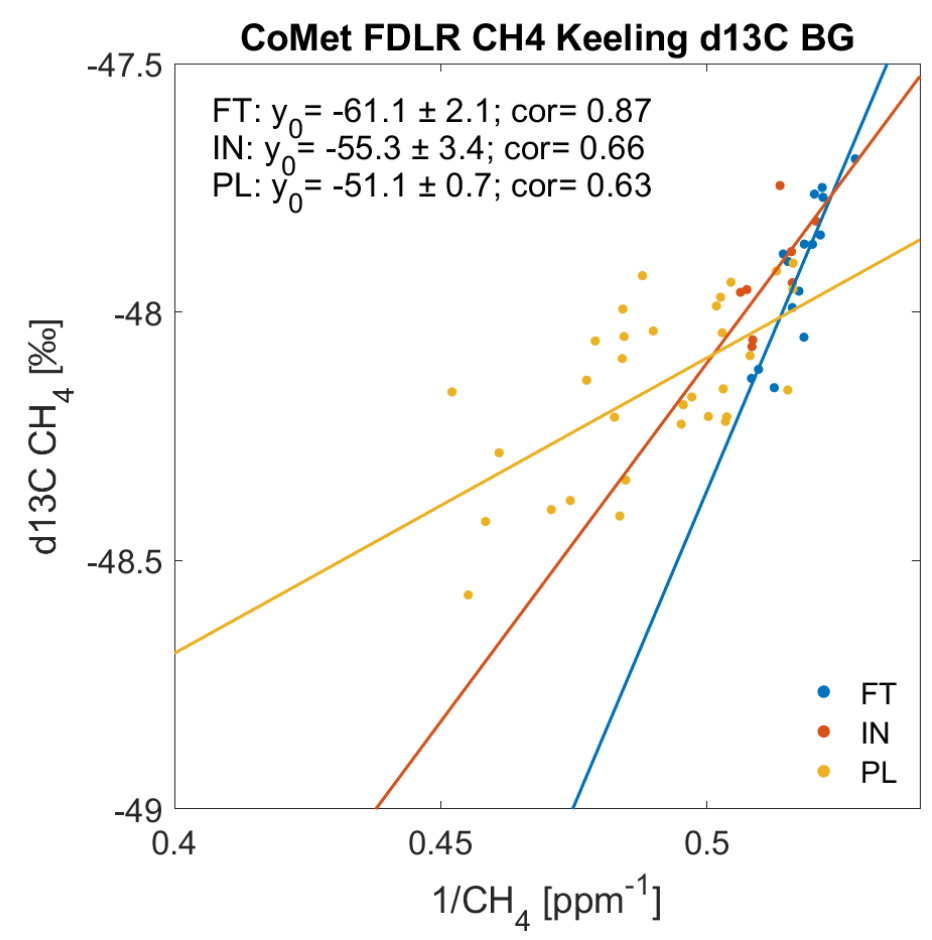

Observed isotopic ratios have to be corrected for the dilution with the background air masses to derive the source signatures. We use keeling plots and orthogonal distance regression.

FT and IN samples represent the "clean end member" of the Keeling plot. Here we also made a Keeling plot for these sub-sets separately, because it turns out that there is a good correlation between delta values and $\mathrm{CH}_{4}$ in these "background" samples. 


\section{Upper Silesian Coal Basin signatures per flight}

\begin{tabular}{|c|c|c|c|c|c|c|c|}
\hline Flight & $\begin{array}{c}\text { Wind } \\
\text { direction }\end{array}$ & Target region & $\begin{array}{l}\text { \# Flasks } \\
\text { in PBL }\end{array}$ & $\begin{array}{l}\delta 13 C \mathrm{CH}_{4} \\
{[\%]}\end{array}$ & $\begin{array}{l}\text { SE } \delta 13 C \\
{[\% 0]}\end{array}$ & $\begin{array}{l}\delta \mathrm{D} \mathrm{CH}_{4} \\
{[\% 0]}\end{array}$ & $\begin{array}{l}\text { SE } \delta D \\
{[\%]}\end{array}$ \\
\hline 1 & S & Southwest & 3 & -54.7 & 1.3 & -261 & 53 \\
\hline 2 & S & Southwest & 3 & -52.0 & 2.6 & -261 & 15 \\
\hline 3 & $\mathbf{N}$ & North & 7 & -49.4 & 1.3 & -219 & 12 \\
\hline 4 & NE & Entire & 0 & - & - & - & - \\
\hline 5 & NE & Entire & 7 & -49.6 & 2.0 & -228 & 24 \\
\hline 6 & E & South & 3 & -52.4 & 1.8 & -223 & 12 \\
\hline 8 & SE & South & 4 & -54.0 & 1.2 & -236 & 14 \\
\hline 9 & NW & Entire & 7 & -49.9 & 2.4 & -235 & 31 \\
\hline 10 & NE & Southeast & 4 & -49.3 & 7.6 & -237 & 10 \\
\hline $\mathrm{PL}$ & - & - & 32 & -50.9 & 0.7 & -226 & 9 \\
\hline
\end{tabular}




\section{Sub-regional isotopic signatures}
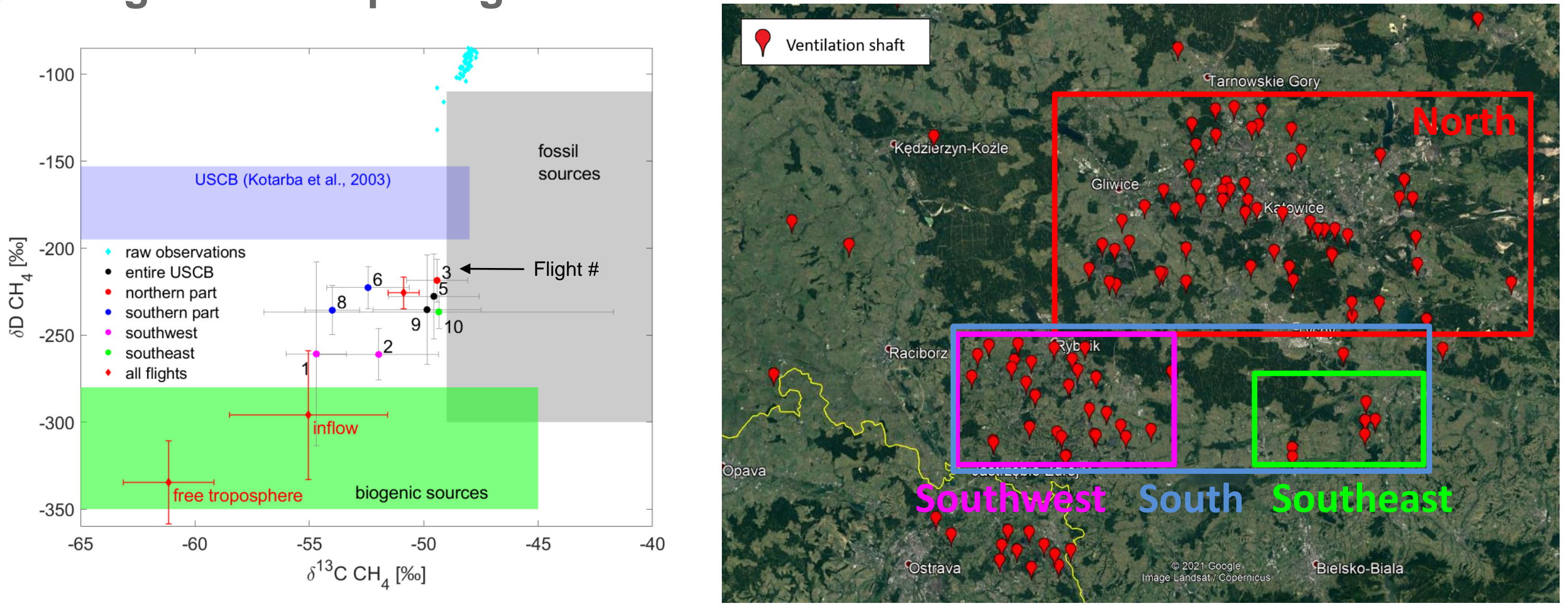

Isotopic signatures vary for different flights and parts of the USCB.

The observed $\mathrm{CH}_{4}$ variability in the inflow and free troposphere originates from biogenic sources.

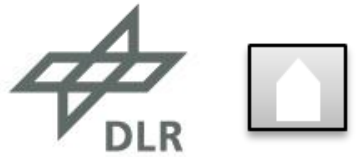




\section{Ground-based samples}

A total of 58 signatures from ventilation shafts and other sources were gathered in the USCB in cooperation with $\mathrm{MEMO}^{2}$.

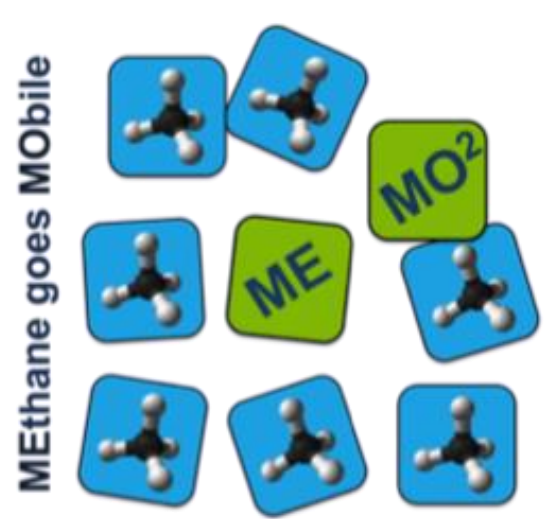

MEasurements and MOdelling

https://h2020-memo2.eu/
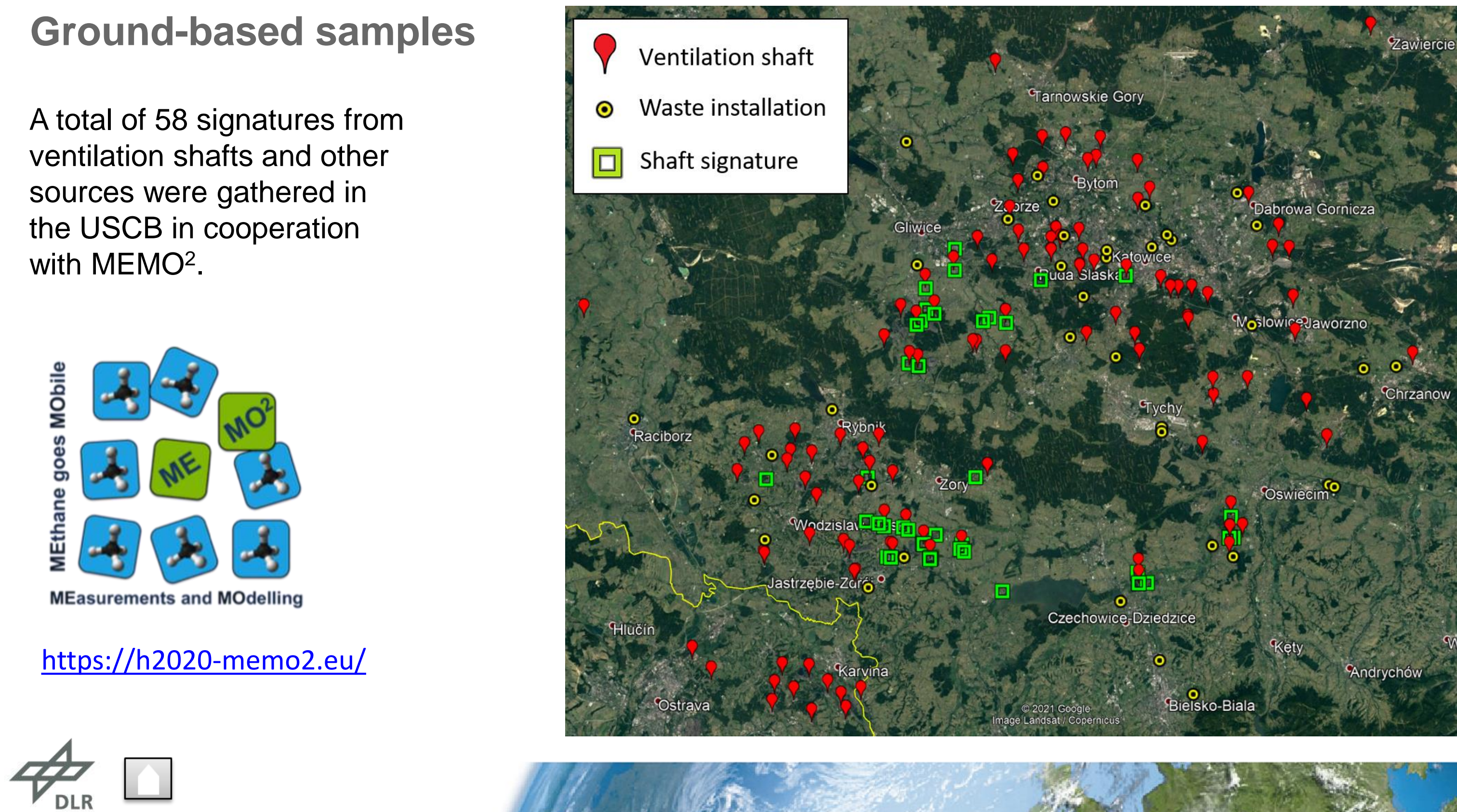


\section{Ground samples from individual ventilation shafts}

For each signature several air samples were taken outside of the ventilation facilities, analyzed via mass spectrometry and corrected for dilution processes. Pniowek samples from inside the shaft show that signatures of inside and outside sampling agree. A spread in signatures of one shaft is usually associated with temporal changes of the source signature caused by different sections of the mine being ventilated on different days. A mean signature for each shaft was determined for comparison to airborne signatures.

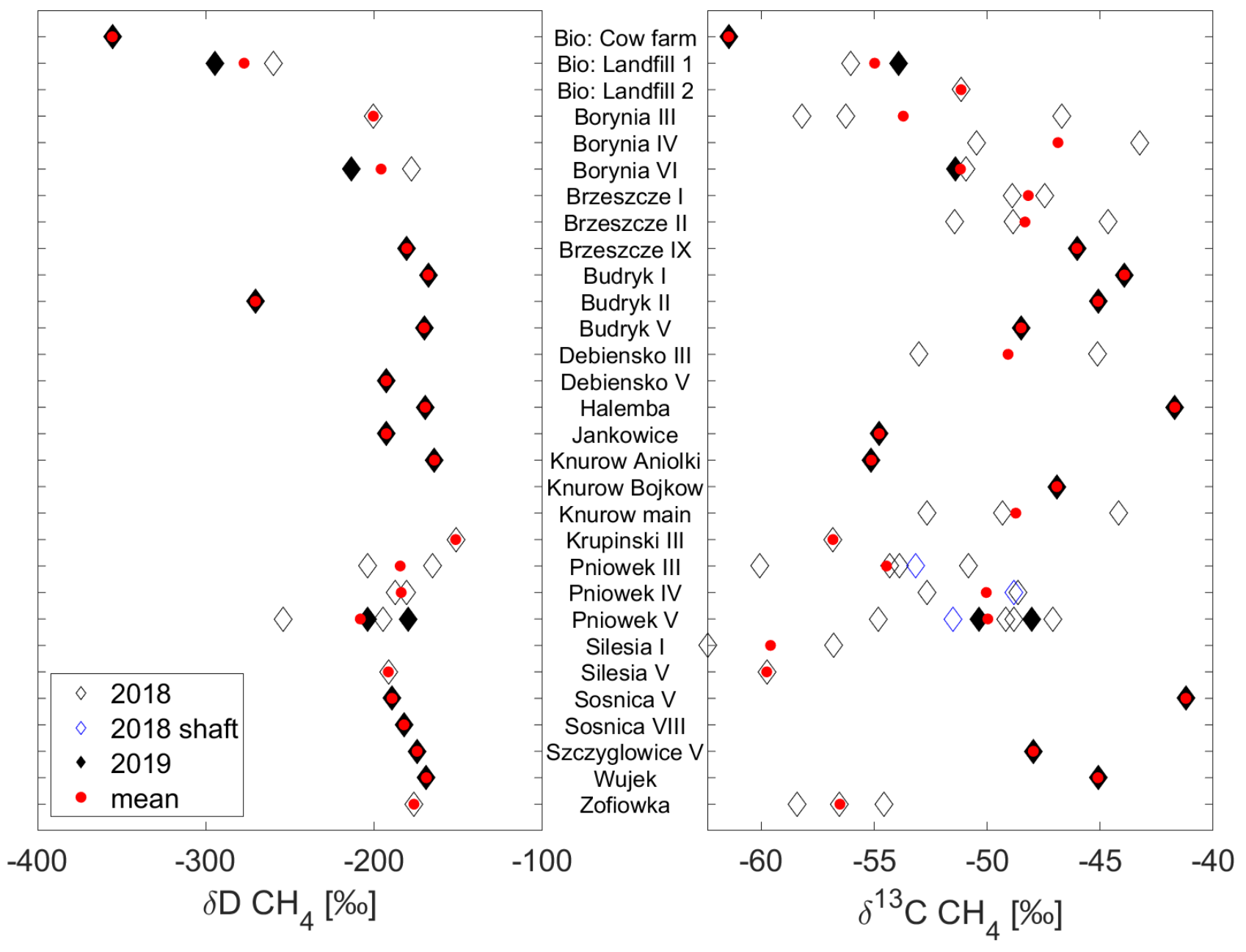




\section{Airborne and shaft signature}

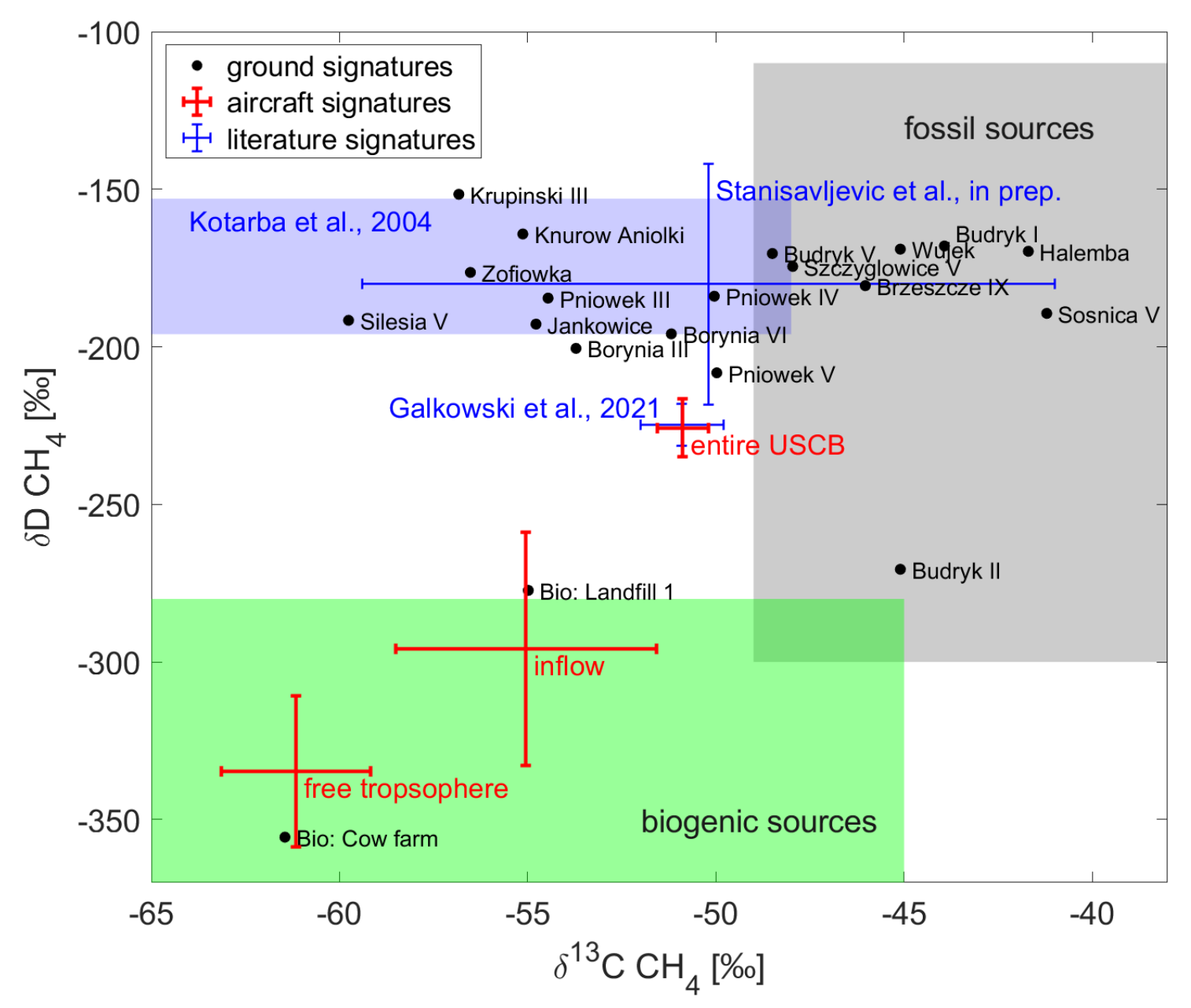

The $\delta^{13} \mathrm{C}$ signatures of individual shafts are in the upper range and higher than previous signatures found by Kotarba et al. (2004), while $\delta D$ signatures are in the range of previous signatures.

Compared to the aircraft observations, the ground studies show more positive signatures in $\delta D$. The methane emissions sampled from the aircraft contain $60 \%$ coal mine methane and $40 \%$ biogenic methane assuming the following signatures:

$\delta D_{\text {aircraft }}=-226 \%$

$\delta D_{\text {coal }}=-180 \%$

$\delta D_{\text {biogenic }}=-300 \%$

EDGAR v5.0 gives a ratio of $92 \%$ fossil methane sources and only $8 \%$ from biogenic sources (waste + cows) for the USCB.
EDGAR v50 CH4: $663 \mathrm{kt} / \mathrm{a}$ $2 \% \quad 3 \% \quad 2 \% \quad 4 \% \quad 2 \%$

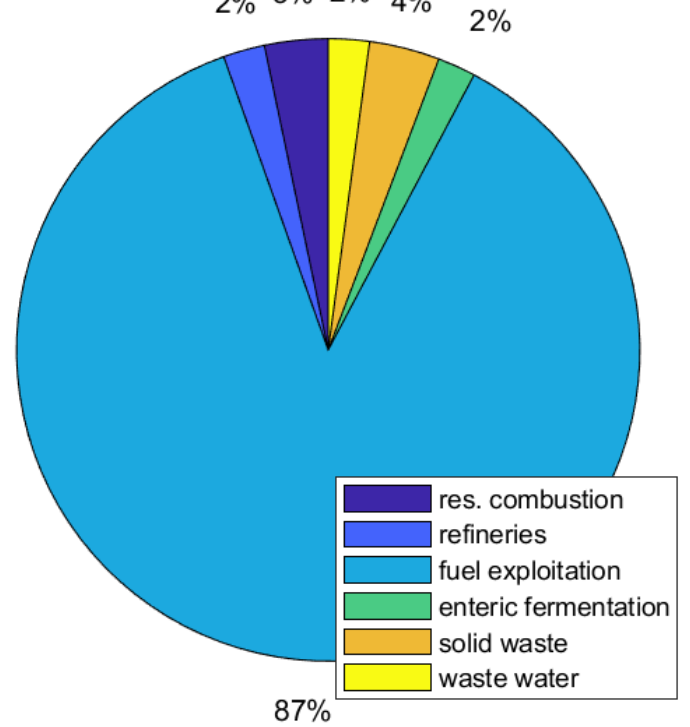




\section{$\operatorname{MECO}(\mathrm{n}) \mathrm{global} /$ regional model}

"MESSyfied ECHAM and COSMO models nested $n$ times"

Global model with 3 regional nests at $50 \mathrm{~km}, 7 \mathrm{~km}$ and $2.8 \mathrm{~km}$ horizontal resolution

\section{Nudging}

- Analysis simulation started 1st of April 2018 and is nudged towards ECMWF operational analysis data towards divergence: vorticity, temperature and the logarithm of surface pressure. SST and SIC are prescribed as boundary conditions.

\section{Emission inventory combination}

- Anthropogenic includ. Rice : EDGAR5 $\left(0.1^{\circ} \times 0.1^{\circ}\right)$, year 2012, indiv. Sectors

- Natural: EMPA inventory $\left(1^{\circ} \times 1^{\circ}\right)$ (Frank et al., 2018), 2012

\section{Initial conditions}

- Methane isotopologues and a posteriori emissions from Frank et al., (2018), (Restart 31.03.2012)

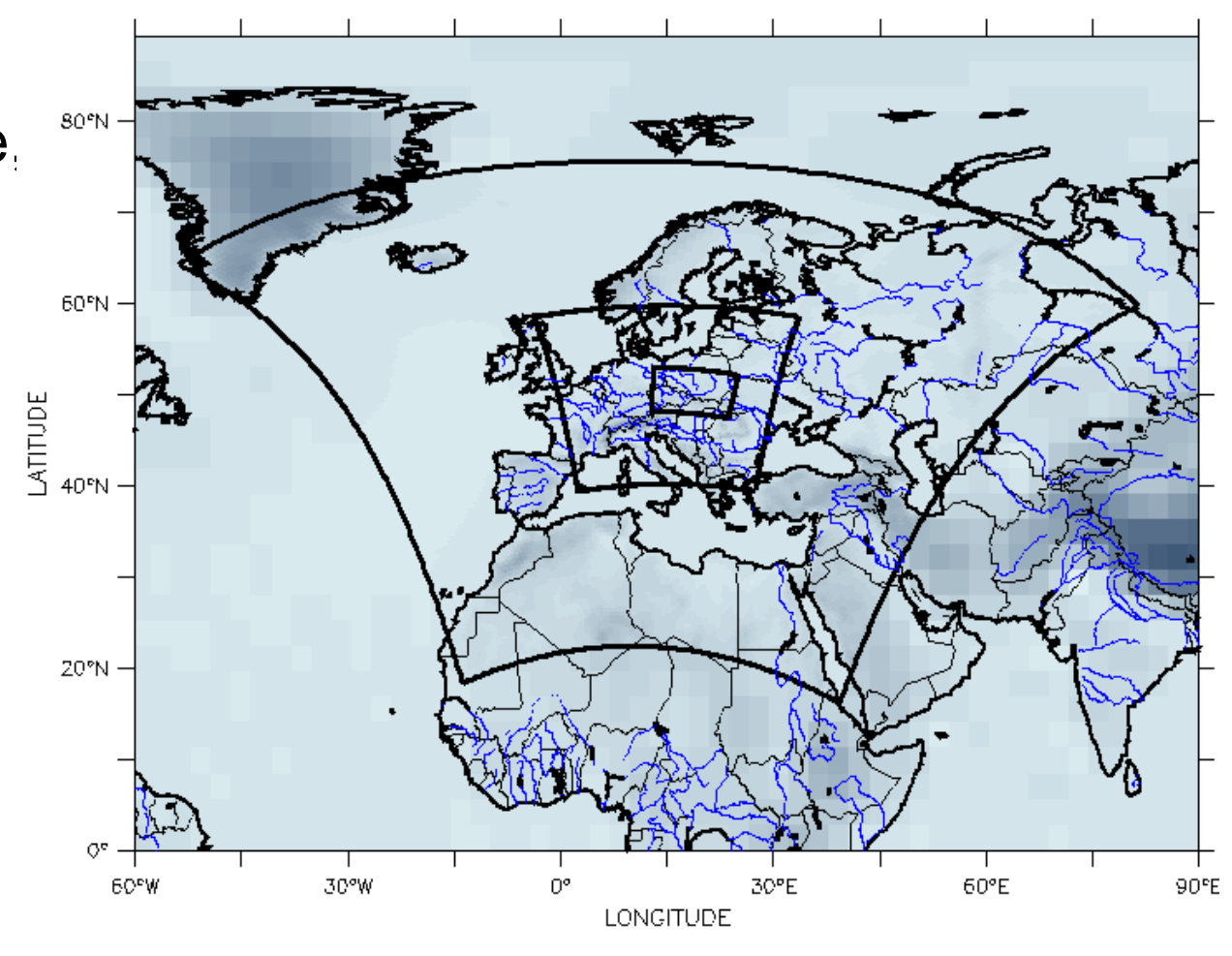




\section{Isotopic source signatures used in the MECO(n) model}

\begin{tabular}{|l|l|l|} 
& $\delta^{13} \mathrm{C}_{4}[\% 0]$ & $\delta \mathrm{C} \mathrm{CH}_{4}[\% 0]$ \\
\hline Biomass burning & -23 & -213 \\
\hline Wetlands & -59.4 & -336.2 \\
\hline Termites & -63.3 & -390 \\
\hline Wild animals & -61.5 & -319 \\
\hline Rice & -63 & -324.3 \\
\hline Volcanoes & -40.9 & -253.4 \\
\hline Ocean & -59 & -220.0 \\
\hline Anthropogenic & -46.8 & -223.5
\end{tabular}

Refinement of anthropogenic source

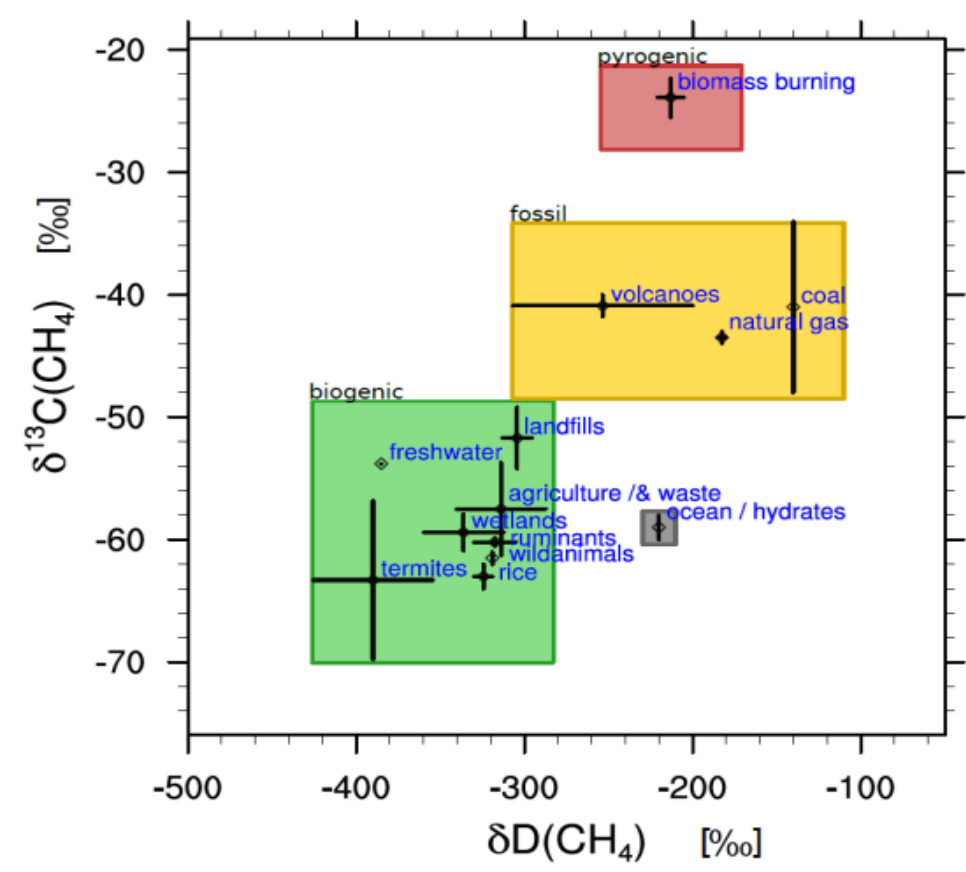

(from Frank et al., 2018)

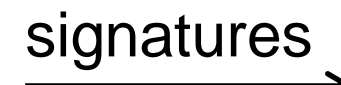

\begin{tabular}{|l|l|l|} 
& $\delta^{13} \mathrm{C} \mathrm{CH}_{4}[\% 0]$ & $\delta \mathrm{D} \mathrm{CH}_{4}[\% 0]$ \\
\hline Livestock & -60.2 & -317.5 \\
\hline Landfills & -51.7 & -304.3 \\
\hline Fossil fuels & -41.7 & -164 \\
\hline
\end{tabular}

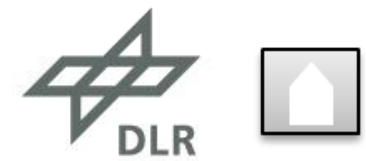




\section{Analysis simulations to check plume representation}

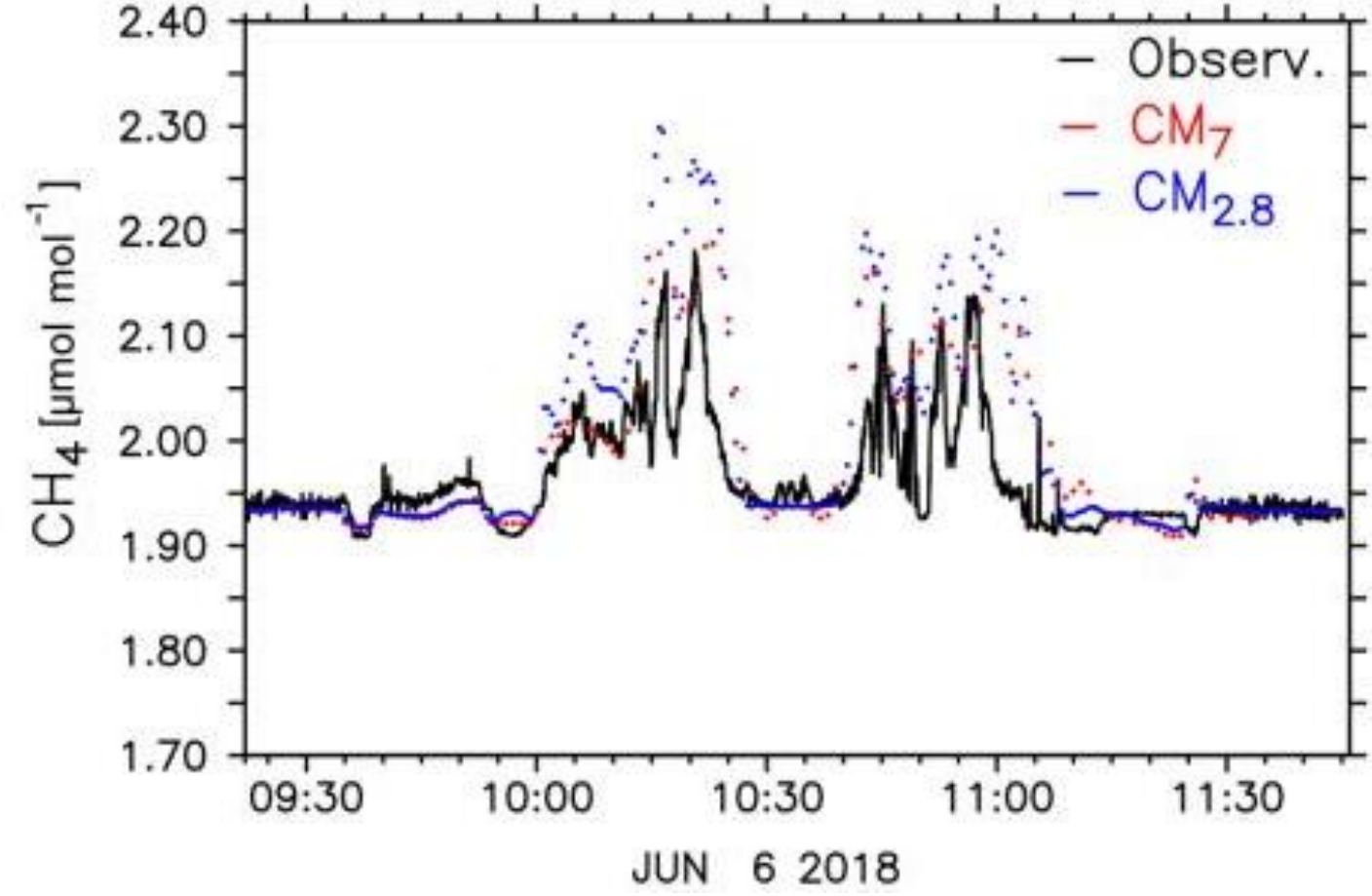

- Plume positions match

- Enhancements are higher in the model (here with EDGARv4.2)

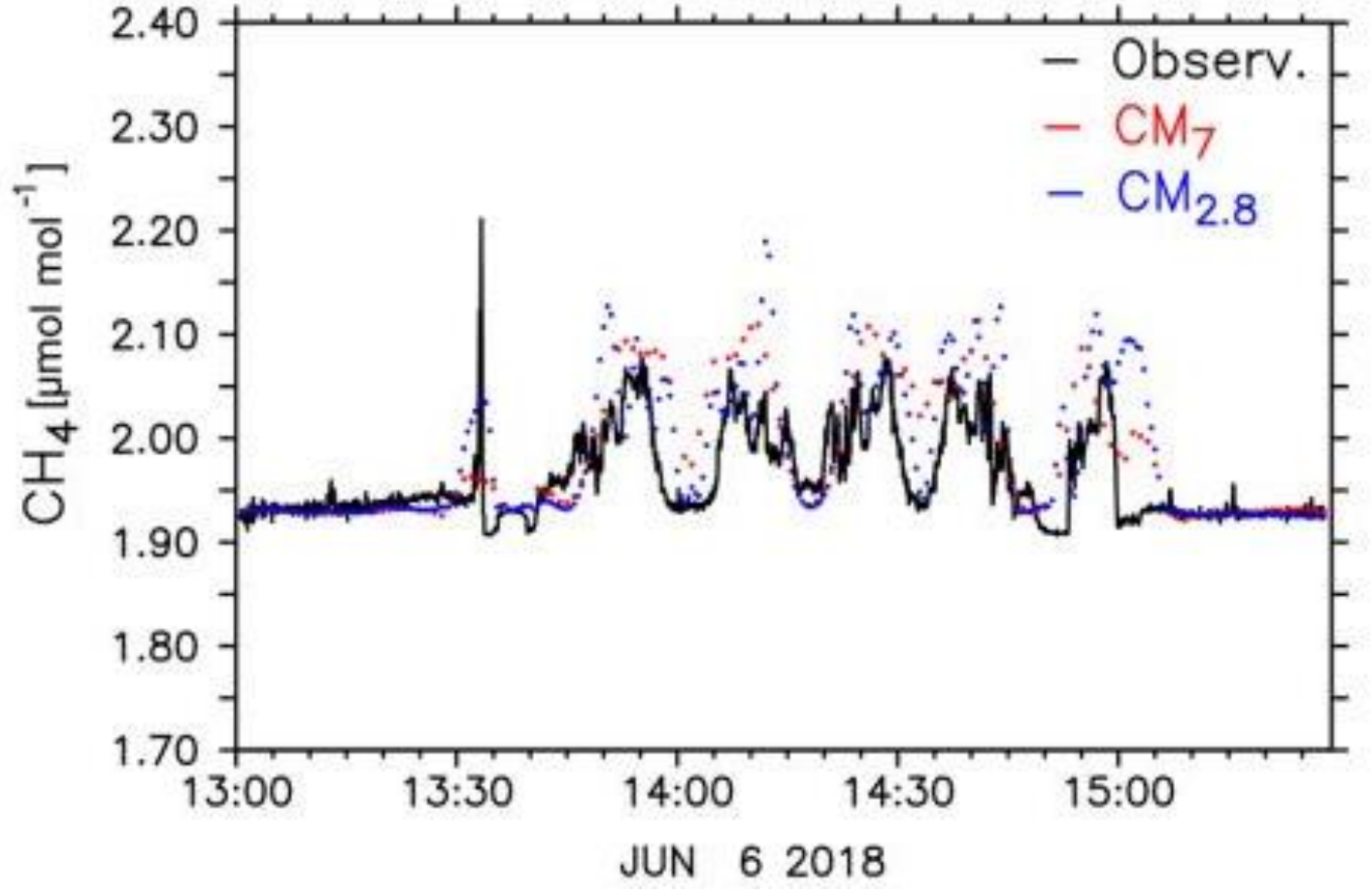

Published by Nickl et al., (2020)

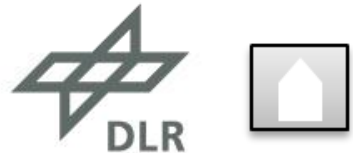




\section{Comparison of model and aircraft in situ and flask samples}
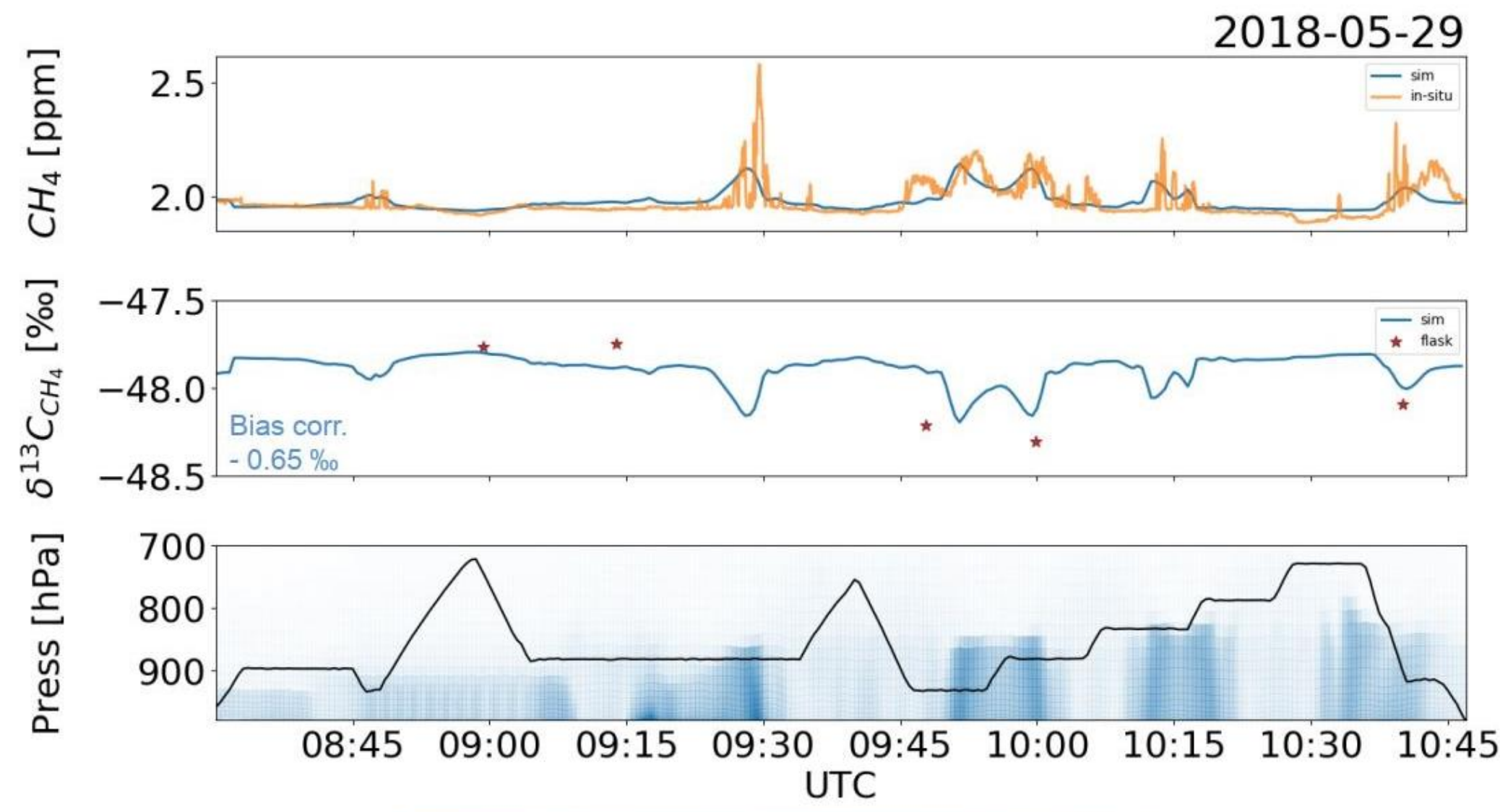

$$
\begin{aligned}
& \begin{array}{lllllll}
-47.7 & -47.6 & -47.5 & -47.4 & -47.3 & -47.2 & -47.1
\end{array} \\
& \delta^{13} C_{\mathrm{CH}_{4}}[\% \text { o] } \quad \text { PhD thesis A. Nickl }
\end{aligned}
$$

The regional model reflects the changes in methane isotopic composition caused by the methane emission from coal mining ventilation.

A comparison with airborne in situ and flask data confirms the changes.

The curtain plot in the lowest panel shows that the isotopic composition varies only within the boundary layer and not in the free troposphere. 


\section{Comparison of model and aircraft isotopic signatures}

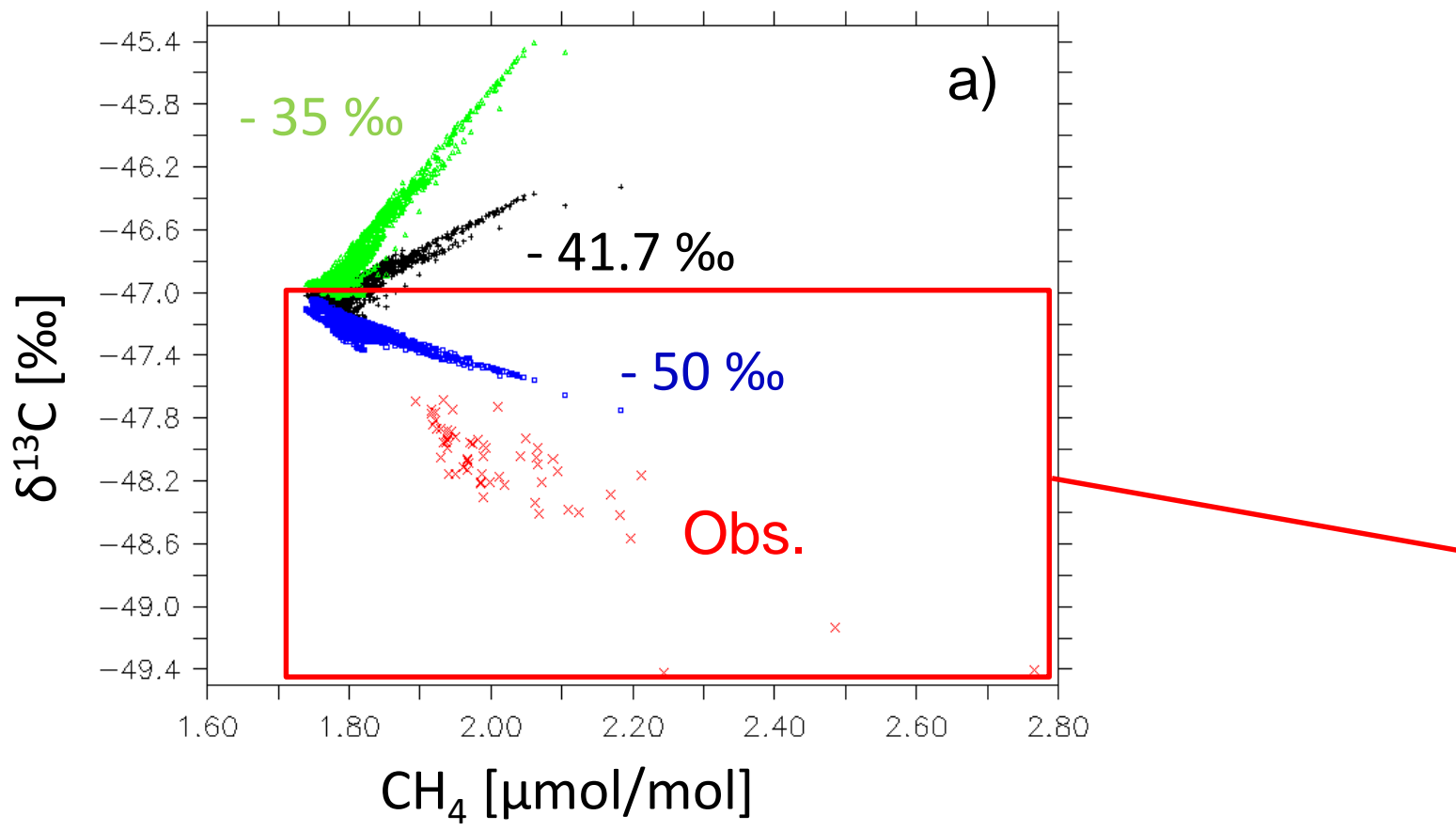

a) $\mathrm{CH}_{4}$ mixing ratio and $\delta^{13} \mathrm{C}$ of three simulations with different assumptions on the coal isotopic source signatures compared to those of the observation

b) Best fit with isotopic source sig for fossil fuel emission $=-50 \%$

\section{The comparison shows three discrepancies:}

- Model bias in the background $\mathrm{CH}_{4}$ mixing ratio

- Model bias in the background isotopic composition

- Small discrepancy in $\delta^{13} \mathrm{C}$ source signature

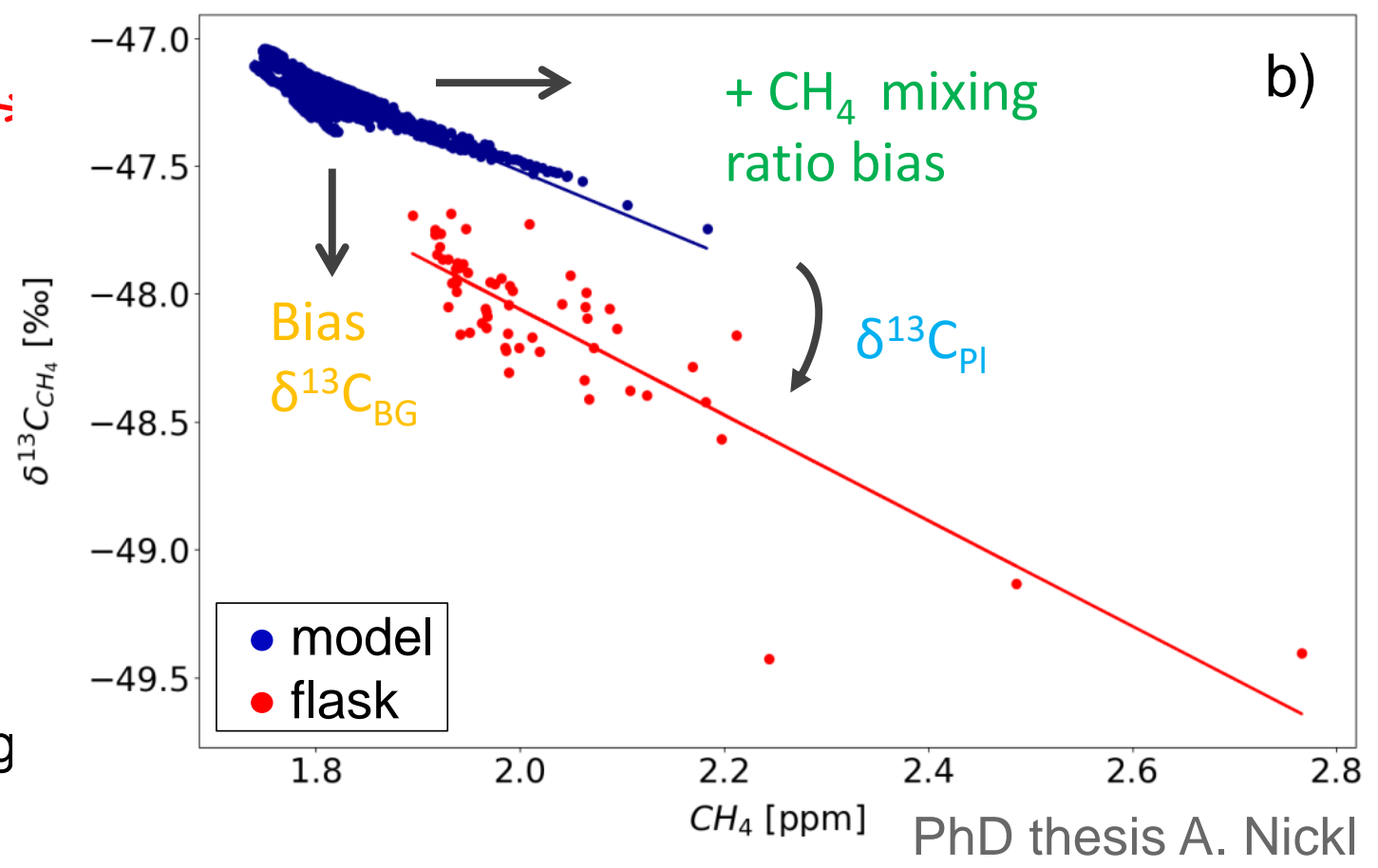




\section{Conclusions}

- Isotopic signatures of methane derived from the aircraft vary for different parts of the USCB.

- The observed $\mathrm{CH}_{4}$ variability in the inflow and free troposphere originates from biogenic sources.

- Coal mine methane signatures vary strongly from mine to mine and shaft to shaft and also over time.

- $\delta D$ signatures indicate that methane emissions sampled from the aircraft contain about $60 \%$ coal mine methane and $40 \%$ biogenic methane from the waste sector.

- The regional model reflects the changes in methane isotopic composition caused by the methane emission from coal mining ventilation.

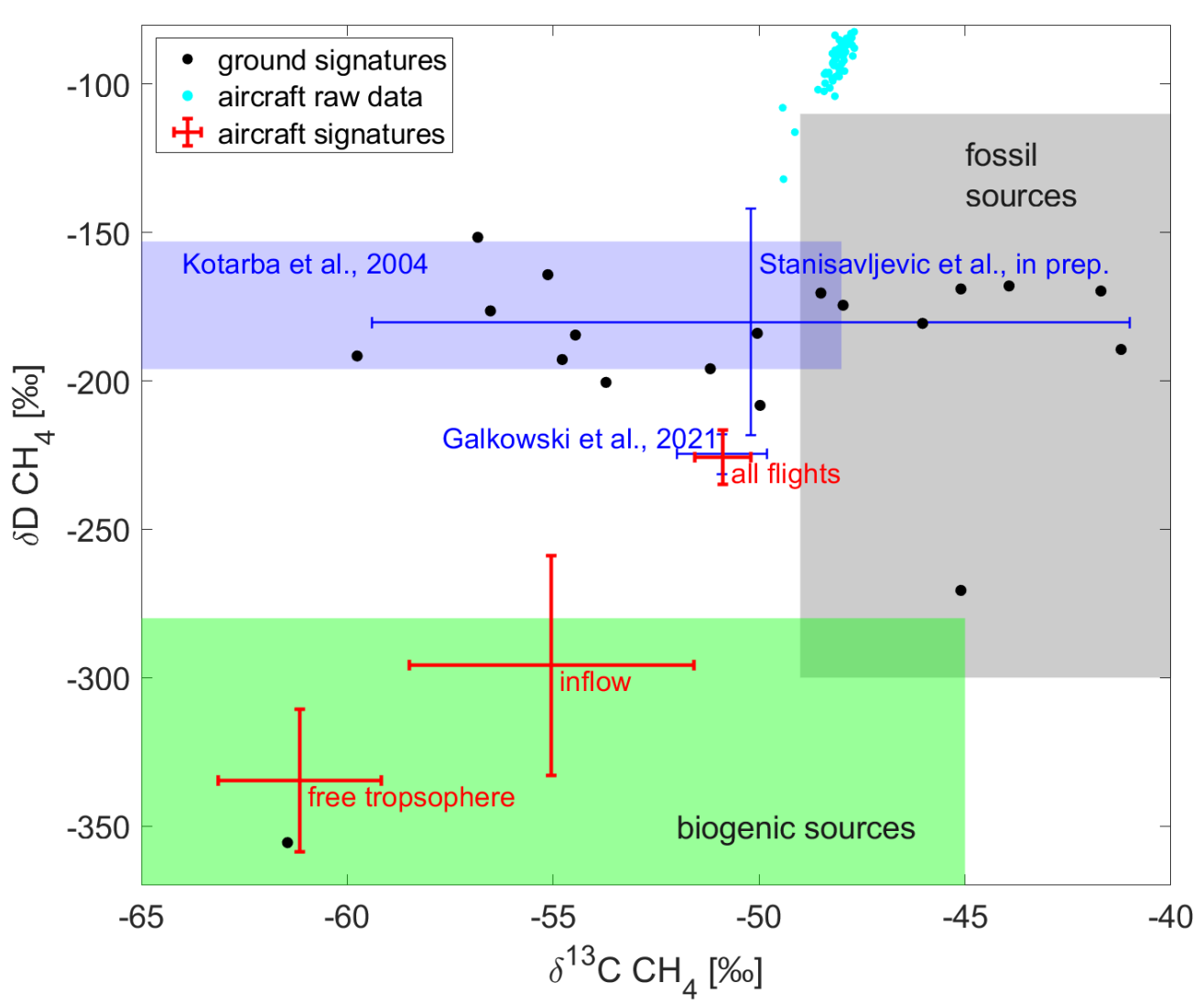




\section{References}

- Fiehn, A., J. Kostinek, M. Eckl, T. Klausner, M. Gałkowski, J. Chen, C. Gerbig, T. Röckmann, H. Maazallahi, M. Schmidt, P. Korbeń, J. Nȩcki, P. Jagoda, N. Wildmann, C. Mallaun, R. Bun, A. L. Nickl, P. Jöckel, A. Fix, and A. Roiger. 2020. "Estimating $\mathrm{CH} 4, \mathrm{CO} 2$, and $\mathrm{CO}$ emissions from coal mining and industrial activities in the Upper Silesian Coal Basin using an aircraft-based mass balance approach." Atmos. Chem. Phys. Discuss. 2020:1-33. doi: 10.5194/acp-2020-282.

- Frank, Franziska. 2018. "Atmospheric methane and its isotopic composition in a changing climate: A modeling study." PhD, Fakultät für Physik, LudwigMaximilians-Universität München.

- Gałkowski, M., A. Jordan, M. Rothe, J. Marshall, F. T. Koch, J. Chen, A. Agusti-Panareda, A. Fix, and C. Gerbig. 2021. "In situ observations of greenhouse gases over Europe during the CoMet 1.0 campaign aboard the HALO aircraft." Atmos. Meas. Tech. 14 (2):1525-1544. doi: 10.5194/amt-141525-2021.

- Kostinek, J., A. Roiger, K. J. Davis, C. Sweeney, J. P. DiGangi, Y. Choi, B. Baier, F. Hase, J. Groß, M. Eckl, T. Klausner, and A. Butz. 2019. "Adaptation and performance assessment of a quantum and interband cascade laser spectrometer for simultaneous airborne in situ observation of $\mathrm{CH} 4, \mathrm{C} 2 \mathrm{H} 6$, CO2, CO and N2O." Atmos. Meas. Tech. 12 (3):1767-1783. doi: 10.5194/amt12-1767-2019.

- Kotarba, Maciej J. 2001. "Composition and origin of coalbed gases in the Upper Silesian and Lublin basins, Poland." Organic Geochemistry 32 (1):163180. doi: 10.1016/S0146-6380(00)00134-0.
- Kotarba, Maciej J., and Michael D. Lewan. 2004. "Characterizing thermogenic coalbed gas from Polish coals of different ranks by hydrous pyrolysis." Organic Geochemistry 35 (5):615-646. doi: 10.1016/j.orggeochem.2003.12.001.

- Mallaun, C., A. Giez, and R. Baumann. 2015. "Calibration of 3-D wind measurements on a single-engine research aircraft." Atmos. Meas. Tech. 8 (8):3177-3196. doi: 10.5194/amt-8-3177-2015.

- Necki, Jaroslaw, Miroslaw Zimnoch, Alina Jasek, Luksz Chmura, Michal Galkowski, Wojciech Wolkowicz, and Patryk Lakomiec. 2017.

"Characterisation of methane isotope composition over the Silesian Coal Basin, Poland." European Geoscience Union General Assembly, Vienna.

- Nickl, A. L., M. Mertens, A. Roiger, A. Fix, A. Amediek, A. Fiehn, C. Gerbig, M. Galkowski, A. Kerkweg, T. Klausner, M. Eckl, and P. Jöckel. 2020. "Hindcasting and forecasting of regional methane from coal mine emissions in the Upper Silesian Coal Basin using the online nested global regional chemistry-climate model MECO(n) (MESSy v2.53)." Geosci. Model Dev. 13 (4):1925-1943. doi: 10.5194/gmd-13-1925-2020.

- Sherwood, O. A., S. Schwietzke, V. A. Arling, and G. Etiope. 2017. "Global Inventory of Gas Geochemistry Data from Fossil Fuel, Microbial and Burning Sources, version 2017." Earth Syst. Sci. Data 9 (2):639-656. doi: 10.5194/essd-9-639-2017.

- Zazzeri, G., D. Lowry, R. E. Fisher, J. L. France, M. Lanoisellé, B. F. J. Kelly, J. M. Necki, C. P. Iverach, E. Ginty, M. Zimnoch, A. Jasek, and E. G. Nisbet. 2016. "Carbon isotopic signature of coal-derived methane emissions to the atmosphere: from coalification to alteration." Atmos. Chem. Phys. 16 (21):13669-13680. doi: 10.5194/acp-16-13669-2016. 